\title{
Business Executive Perspectives on Quantitative Easing: An Agent-Based Exploration
}

\author{
O. Homer Erekson* \\ Professor of Managerial Economics and Strategy \\ Texas Christian University \\ TCU Box 298530 \\ Fort Worth, Texas 76129 \\ USA \\ Kirby C. Schulz \\ Associate, Infrastructure and Energy Investment Banking \\ Macquarie Capital \\ USA \\ 500 Dallas Street \\ Houston, Texas 77002
}

\begin{abstract}
The effectiveness of quantitative easing has been studied from several angles and perspectives typically using traditional macroeconomic modelling. Some scholars believe that these models fail to explain the behavior of individuals when confronted with financial crises and call for an alternative agent-based approach. In this paper, we provide the results from a survey of senior level business executives regarding their understanding of and approach to the recession of 2008 and quantitative easing. There was consistent evidence that respondents believed quantitative easing had a much stronger impact on other executives than for themselves personally.
\end{abstract}

Keywords : quantitative easing; business executive perspectives; agent framework

\section{Introduction}

The financial crises in 2007 and 2008 led to numerous articles examining the causes of these crises and the subsequent rather unconventional monetary policies used by the Federal Reserve to address them. Primary among these was quantitative easing. This policy action involved changes in the composition and size of the central bank's balance sheet designed to ease liquidity and improve credit conditions (Blinder, 2010).

With the 2008 financial panic, the Federal Reserve used aggressive changes in their balance sheets to stabilize financial markets and move the economy towards more normal economic activity. On December 16, 2008, the Federal Open Market Committee (FOMC) reduced the federal funds rate tozero to $1 / 4$ percent. The committee released a statement saying that, "the policy going forward will be to support the functioning of financial markets and stimulate the economy through open market operations and other measures that sustain the size of the Federal Reserve's balance sheet at a high level" (Carlson and Wakefield, 2009). This was just the beginning of five years of monetary policy implemented by the Federal Reserve. The decision to reduce the interest rate to almost zero established what is known as the zero lower bound. Carlson and Wakefield continue to frame the situation by recognizing that the monetary base jumped from $\$ 850$ billion in late August 2008 to almost $\$ 1.7$ trillion at the end of 2008. Subsequently, the Federal Reserve implemented several rounds of quantitative easing with the third round beginning in September 2012. This round entailed purchasing $\$ 40$ billion in mortgage-backed securities and $\$ 45$ billion in long-term T-bonds each month until the labor market improved. The initial action to bring the federal funds rate close to zero was one of the main conventional monetary policy tools (Carlson, Haubrich, Cherny, and Wakefield, 2009). The president of the Federal Reserve Bank of San Francisco gave a presentation in October 2013 to explain two unconventional policies that the Federal Reserveimplemented stating, "because of the zero lower bound on the federal funds rate, the Federal Reserve introduced alternative ways to ease financial conditions and thereby stimulate economic growth and job creation" (Williams, 2013). He identified these alternative actions as large-scale asset purchases, otherwise known as quantitative easing, and forward policy guidance, communicating likely future Fed policy actions.

Some distinct differences set these decisions made by the Fed apart. First, Ben Bernanke, who led all three rounds of this program, made it very clear that there was a difference between "credit easing" and "quantitative easing." Credit easing, which has been used in the past, pushes money into specific markets that are broken. 
On the other hand, quantitative easing increases the overall money supply in general. Also, prior to these decisions, the Fed focused on buying and selling Treasury securities when making changes to the money supply. However, during quantitative easing, many mortgage-backed securities were purchased in addition to treasuries. This in turn "lowered long-term interest rates which stimulated the auto market, the housing market, business investment, and other types of economic investment" (Williams, 2013). This focus on specific markets remained controversial within the Fed and in the eyes of investors, but the purchase of mortgage-backed securities was implemented during the first and third rounds of quantitative easing.

Quantitative easing has been studied from several angles and perspectives since 2008. The common themes that have developed throughout the research are split into three distinct groups. First, some research has focused on whether quantitative easing was necessary from the start and whether the economy could have recovered without it. The second theme involves examiningwhether quantitative easing resulted in sustained recovery or whether there wereartificial bubbles in the market resulting from the Fed's actions. Finally, the third theme involved long-term impact on the U.S. and global economies (Bhattarai, Chatterjee, and Park, 2015).

This research typically used traditional macroeconomic modelling, although evolving over time. Gertler and Gilchrist (2018: 3) note that early studies incorporated "workhouse macroeconomic models [assuming] frictionless financial markets" which were "not able to anticipate the crisis, nor to analyze how the disruption of credit markets changed what initially appeared like a mild downturn in the Great Recession."

In this paper, we offer an approach based on an agent-based perspective and provide the results from a survey of senior level business executives regarding their understanding of and approach to the recession of 2008 and quantitative easing.

\section{Conceptual Basis for an Agent-based Approach}

An important dimension of the recession of 2008 were the frictions affecting borrowing and lending and the resulting connection to balance sheet strength and credit access. Even though the FOMC cut the nominal interest rate basically to zero, it resulted in a "liquidity trap" undermining the ability of the central bank to stimulate the economy. Although the FOMC cut the federal funds rate from an initial target of 5.25\% in September 2007 essentially to zero in December 2008, there was no perceived sense of urgency (Blinder, 2010).

Moreover, Gertler and Gilchrist (2018) suggest another friction in the context of an agency problem where lenders created an "external finance" premium by imposing constraints such as credit limits, collateral requirements, and bankruptcy contingencies that made raising funds externally more expensive than using internal funds (Bernanke and Gertler, 1995).

It is within this context that we examine the perspective of business executives about quantitative easing and their reaction. Whereas most quantitative easing research has been based on macroeconomic modeling and testing, we examine individual behavior of executives, addressing an important gap in the literature.

Bookstaber (2017) has supported the need for an alternate, agent-based approach to understanding the causes and results of financial crises. He argues "it is that complexity increases risk of the 'unknown unknowns' variety ... a system is complex if you cannot delineate all its states (i.e., radical uncertainty). You may think you have the system figured out, but every now and then something happens that leaves you scratching your head." A natural reaction then is to assume an ergodic process, where an individual assumes "the same old, same old . . . it follows the same probabilities today as it did in the distant past and will in the distant future" (Bookstaber, 2017: 17).

Bookstaber discusses how people's reactions to events influence the behavior of other people, which then reverberate back to the initial agents. He argues that financial crises are inherently emergent phenomena, "when system wide dynamics arise unexpectedly out of the activities of individuals in a way that is not simply an aggregation of that behavior ... emergence can create a helter-skelter world where people who are minding their own business and doing what seems reasonable produce strange, unexpected results . . . Did you cause the economic meltdown of 2007-2009? Neither did anybody else. We still had one, though. That's emergence." (Bookstaber, 2017: 17)

For instance, he argues that the May 6, 2010 U.S. equity market "flash crash" resulted because liquidity dried up. There was a difference in time frames between demanders and suppliers as the market dropped more than seven percent in a matter of fifteen minutes. High-frequency electronic trading created a crisis of liquidity where liquidity demand came in faster than liquidity supply (Bookstaber, 2017: 147). Thus, the demand for selling occurred more quickly than the price could communicate and attract needed supply (Bookstaber, 2017: 151). 
In a CNN.Money interview, Jeremy Grantham commented, "We got so good at denial. The Fed was in denial, the Treasury was in denial, and the bosses of Merrill Lynch and Lehman were in denial. And yet this crisis was the most widely heralded 'surprise' in the history of finance . . . They believed their risk models, which said they had a diversified portfolio, so their investments couldn't go down together ... Psychology is central in these kinds of markets. Don't panic, that's the No. 1 rule, and think long term.” (Revell and Light, 2008).

Reinhart and Rogoff (2009) likewise argued that financial crises are fundamentally different from cyclical recessions. Rather than resulting from a breakdown of the banking system, in a financial crisis the banking system faces liquidity and solvency challenges from being over-extended in credit markets.

Putnam (2013) argued that with near-zero short-term interest rates, traditional macroeconomic models would not explain behavior of consumers or corporations. During the period of deleveraging during2008-2011, decisions by corporations to invest in new plant and equipment or to hire new workers were not interest rate sensitive.

Madera (2019) summarizes evidence about decision making when there are uncertain factors at play. He proposes that, "When taking a decision, a subject relies on their own assessments of the uncertain factors, which can be both directly accessible to the subject for perception at present and inaccessible at the moment because they will actualize in future only ... They carry no reliable information about the estimated object and rather evidence that the minds of [people] are subject to heuristics and mental traps (the trap of conceit in particular)."

\section{Executive Results}

It is within this context that we sought to examine the perspectives of executives about the financial crisis of 2008 and their reaction to quantitative easing. Bookstaber (2017: 156) suggests, "if there is one place where a recognition of the agents and their actions - and the use of agent-based methods to determine the effect - is needed, it is in assessing crisis liquidity dynamics.”

A survey instrument was created to examine the degree to which quantitative easing affected the decision making of senior business executives. As a primer and reminder to survey participants, the following statement was included: In 2008, the U.S. economy spiraled into a recession due to the collapse of the housing market. This caused banks and investors to stop lending, the stock market to endure its worst fall since the Great Depression, and unemployment to soar. On December 16, 2008, the Federal Open Market Committee (FOMC) stepped in to establish a target for the federal funds rate at $0 \%$ to $0.25 \%$. Unconventional monetary policies were also introduced. This included large-scale asset repurchases, otherwise known as quantitative easing $(Q E)$, and forward policy guidance, which communicated likely future Fed policy actions. The monetary base jumped from $\$ 850$ billion in late August 2008 to almost $\$ 1.7$ trillion at the end of 2008.

The survey had two sections used for comparison: the first section asked questions about decisions that the individual made in reaction to quantitative easing; the second section asked questions about how the executives believed business executives as a whole reacted to quantitative easing. An additional set of questions were included regardingthe individual's understanding of the background of quantitative easing and resulting outlook for the economy. Appendix A contains the full survey questions.

The survey was distributed to a sample of senior business leaders, with thirty-eight responses received. The demographic breakdown of these responses is shown in Table 1. 
Table 1. Demographic Profile of Survey Respondents

\begin{tabular}{|c|c|c|c|}
\hline \multicolumn{4}{|c|}{ Executive Survey Demographic Information } \\
\hline & & Number & Percent \\
\hline \multirow[t]{6}{*}{ Current Position } & $\mathrm{CEO}$ & 13 & $34.21 \%$ \\
\hline & $\mathrm{COO}$ & 2 & $5.26 \%$ \\
\hline & CFO & 3 & $7.89 \%$ \\
\hline & Other C-Level & 10 & $26.32 \%$ \\
\hline & Other Managerial & 7 & 18.42 \\
\hline & Non-Managerial & 3 & $7.89 \%$ \\
\hline \multirow[t]{7}{*}{ Industry } & Energy & 3 & $7.89 \%$ \\
\hline & Manufacturing & 6 & $15.79 \%$ \\
\hline & $\begin{array}{l}\text { Information } \\
\text { Technology }\end{array}$ & 1 & $2.63 \%$ \\
\hline & Finance \& Insurance & 17 & $44.74 \%$ \\
\hline & Health Care & 1 & $2.63 \%$ \\
\hline & Other-For Profit & 9 & $23.68 \%$ \\
\hline & Other-Nonprofit & 1 & $2.63 \%$ \\
\hline \multirow{5}{*}{$\begin{array}{l}\text { Years of Experience } \\
\text { in the Industry }\end{array}$} & $1-5$ & 2 & $5.26 \%$ \\
\hline & $6-10$ & 2 & $5.26 \%$ \\
\hline & $11-15$ & 3 & $7.89 \%$ \\
\hline & $16-20$ & 5 & $13.16 \%$ \\
\hline & $20+$ & 26 & $68.42 \%$ \\
\hline
\end{tabular}

Each survey question was based on a seven-point scalethat ranged from strongly disagree (1) to strongly agree (7). The questions regarding what executives thought individually and what executives thought about business leader decisions as a whole mirrored each other in order to more easily compare the results. Thirty-eight respondents completed the first section and thirty-five the second.

The null hypotheseswere that quantitative easing did notaffect the decision making of individuals or the perception of individuals about business decisions by other executives. These hypotheses were tested using analysis of variance (ANOVA) tests, as summarized in Table 2. 
Table 2 ANOVA Survey Results

\begin{tabular}{|c|c|c|c|c|c|c|c|c|}
\hline & $\begin{array}{l}\text { Stro } \\
\text { ngly } \\
\text { disag } \\
\text { ree }\end{array}$ & $\begin{array}{l}\text { Disa } \\
\text { gree }\end{array}$ & $\begin{array}{l}\text { Somew } \\
\text { hat } \\
\text { disagree }\end{array}$ & \begin{tabular}{l}
\multicolumn{1}{c}{ Neit } \\
her \\
agree or \\
disagree
\end{tabular} & $\begin{array}{l}\text { Somew } \\
\text { hat agree }\end{array}$ & $e^{\text {Agr }}$ & $\begin{array}{c}\text { Stron } \\
\text { gly agree }\end{array}$ & $\begin{array}{l}\quad \text { Weig } \\
\text { hted } \\
\text { average }\end{array}$ \\
\hline $\begin{array}{l}\text { Impacte } \\
\text { d } \quad \text { short- } \\
\text { term } \\
\text { decisions }\end{array}$ & & & & & & & & \\
\hline Personal & $\begin{array}{l}13.16 \\
\%\end{array}$ & $\begin{array}{l}13.16 \\
\%\end{array}$ & $5.26 \%$ & $\begin{array}{l}10.5 \\
3 \%\end{array}$ & $26.32 \%$ & $\begin{array}{l}23.6 \\
8 \%\end{array}$ & $7.89 \%$ & 4.26 \\
\hline Others & $\begin{array}{l}0.00 \\
\%\end{array}$ & $\begin{array}{l}2.86 \\
\%\end{array}$ & $2.86 \%$ & $\begin{array}{l}5.71 \\
\%\end{array}$ & $40.00 \%$ & $\begin{array}{l}40.0 \\
0 \% \\
\end{array}$ & $8.57 \%$ & 5.37 \\
\hline & & & & & & & $\begin{array}{l}F=9.1 \\
6^{* * *}\end{array}$ & $\begin{array}{l}\mathrm{p}=.00 \\
35\end{array}$ \\
\hline $\begin{array}{l}\text { Impacte } \\
\text { d long-term } \\
\text { decisions }\end{array}$ & & & & & & & & \\
\hline Personal & $\begin{array}{l}13.16 \\
\%\end{array}$ & $\begin{array}{l}21.05 \\
\%\end{array}$ & $7.89 \%$ & $\begin{array}{l}5.26 \\
\%\end{array}$ & $26.32 \%$ & $\begin{array}{l}21.0 \\
5 \%\end{array}$ & $5.26 \%$ & 3.95 \\
\hline Others & $\begin{array}{l}0.00 \\
\%\end{array}$ & $\begin{array}{l}5.71 \\
\%\end{array}$ & $8.57 \%$ & $\begin{array}{l}14.2 \\
9 \%\end{array}$ & $31.43 \%$ & $\begin{array}{l}37.1 \\
4 \%\end{array}$ & $2.86 \%$ & 4.94 \\
\hline & & & & & & & $\begin{array}{l}\mathrm{F}=6.6 \\
8^{*}\end{array}$ & $\begin{array}{l}\mathrm{p}=.01 \\
18\end{array}$ \\
\hline \begin{tabular}{l}
\multicolumn{2}{c}{ Maintai } \\
ned short- \\
term liquid \\
assets
\end{tabular} & & & & & & & & \\
\hline Personal & $\begin{array}{l}5.26 \\
\%\end{array}$ & $\begin{array}{l}23.68 \\
\%\end{array}$ & $2.63 \%$ & $\begin{array}{l}15.7 \\
9 \% \\
\end{array}$ & $26.32 \%$ & $\begin{array}{l}18.4 \\
2 \% \\
\end{array}$ & $7.89 \%$ & 4.21 \\
\hline Others & $\begin{array}{l}0.00 \\
\%\end{array}$ & $\begin{array}{l}11.43 \\
\%\end{array}$ & $8.57 \%$ & $\begin{array}{l}11.4 \\
3 \%\end{array}$ & $37.14 \%$ & $\begin{array}{l}20.0 \\
0 \%\end{array}$ & $\begin{array}{l}11.43 \\
\%\end{array}$ & 4.80 \\
\hline & & & & & & & $\begin{array}{l}F=2.3 \\
4\end{array}$ & $\begin{array}{l}p=.13 \\
04\end{array}$ \\
\hline $\begin{array}{l}\text { Contrib } \\
\text { uted to asset } \\
\text { bubble }\end{array}$ & & & & & & & & \\
\hline Personal & $\begin{array}{l}36.84 \\
\%\end{array}$ & $\begin{array}{l}34.21 \\
\%\end{array}$ & $7.89 \%$ & $\begin{array}{l}7.89 \\
\% \\
\end{array}$ & $7.89 \%$ & $\begin{array}{l}2.63 \\
\%\end{array}$ & $2.63 \%$ & 2.34 \\
\hline Others & $\begin{array}{l}5.71 \\
\%\end{array}$ & $\begin{array}{l}22.86 \\
\%\end{array}$ & $17.14 \%$ & $\begin{array}{l}20.0 \\
0 \%\end{array}$ & $14.29 \%$ & $\begin{array}{l}20.0 \\
0 \%\end{array}$ & $0.00 \%$ & 3.74 \\
\hline & & & & & & & $\begin{array}{c}\mathrm{F}=14 . \\
16^{* *}\end{array}$ & $\begin{array}{l}p=.00 \\
03\end{array}$ \\
\hline $\begin{array}{l}\text { Guidanc } \\
\text { e policy } \\
\text { affected } \\
\text { strategic } \\
\text { planning }\end{array}$ & & & & & & & & \\
\hline Personal & $\begin{array}{l}5.41 \\
\%\end{array}$ & $\begin{array}{l}27.03 \\
\%\end{array}$ & $0.00 \%$ & $\begin{array}{l}16.2 \\
2 \%\end{array}$ & $24.32 \%$ & $\begin{array}{l}27.0 \\
3 \%\end{array}$ & $0.00 \%$ & 4.08 \\
\hline
\end{tabular}




\begin{tabular}{|c|c|c|c|c|c|c|c|c|}
\hline Others & $\begin{array}{l}0.00 \\
\%\end{array}$ & $\begin{array}{l}5.71 \\
\%\end{array}$ & $2.86 \%$ & $\begin{array}{l}14.2 \\
9 \%\end{array}$ & $34.29 \%$ & $\begin{array}{l}37.1 \\
4 \%\end{array}$ & $5.71 \%$ & 5.11 \\
\hline & & & & & & & $\begin{array}{l}\mathrm{F}=8.7 \\
1^{* * *}\end{array}$ & $\begin{array}{l}\mathrm{p}=.00 \\
43\end{array}$ \\
\hline $\begin{array}{l}\text { Boosted } \\
\text { dividends } \\
\text { and share } \\
\text { repurchases }\end{array}$ & & & & & & & & \\
\hline Personal & $\begin{array}{l}18.42 \\
\$\end{array}$ & $\begin{array}{l}26.32 \\
\%\end{array}$ & $5.26 \%$ & $\begin{array}{l}36.8 \\
4 \% \\
\end{array}$ & $5.26 \%$ & $\begin{array}{l}7.89 \\
\%\end{array}$ & $0.00 \%$ & 3.08 \\
\hline Others & $\begin{array}{l}2.86 \\
\%\end{array}$ & $\begin{array}{l}8.57 \\
\%\end{array}$ & $11.43 \%$ & $\begin{array}{l}22.8 \\
8 \%\end{array}$ & $28.57 \%$ & $\begin{array}{l}17.1 \\
4 \%\end{array}$ & $8.57 \%$ & 4.51 \\
\hline & & & & & & & $\begin{array}{c}\mathrm{F}=16 . \\
30^{* *}\end{array}$ & $\begin{array}{l}p=.00 \\
01\end{array}$ \\
\hline
\end{tabular}

*Statistically significant at .05

**Statistically significant at .01

Upon analyzing the data, the first conclusion is that individuals thought quantitative easing impacted their personal decisions much less than it impacted the decisions of business leaders as a whole.First, consider the impact of quantitative easing in the short-term. Participants were asked to what degree quantitative easing impacted their shortterm decisions as a business leader and to what degree it impacted other business leaders' short-term decisions. There was a clear and statistically significant difference between the two groups. Respondents strongly conveyed the perspective that quantitative easing had less of an impact on their short-term decisions than for business executives as a whole. Only about $58 \%$ of the executives reported at least somewhat of an effect on short term decisions, as compared to their belief that $89 \%$ of others were impacted. This result is consistent with Bookstaber's conjecture that in decisionmaking, individuals reacted to quantitative easing in personally assuming "the same old, same old."

This difference in perspective held for long-term decision making as well. Putnam (2009: 4) argues that the first phase of quantitative easing, the deleveraging phase from 2008-2011, was different from the two subsequent phases that followed, applying to an economy where the banking system had begun to stabilize and economic growth had resumed. However, he states, "even after the deleveraging phase has ended, if consumers and corporations have little confidence in the likelihood of future economic progress, regardless of the rationale for their lack of confidence, it is also likely that the lack of confidence would trump lower rates in any decision about future consumption or corporate expansion." In our results, respondents also felt that the long run decision making of others was impacted by quantitative easing more than for them personally.

For both short-term decision-making and long-term decision making, these results provide evidence of dominance structuring when considering the impact of quantitative easing (Montgomery, 1983). In making their own personal decisions in this regard, individuals were likely relying upon a set of cognitive heuristics where their personal decisions were rooted in confidence in prior long-term decisions.

Going beyond overall decision making, we then examined the relative perception of executives regarding specific actions related to quantitative easing. One challenge in fueling economic recovery was injecting new resources into the economy. We could not reject the null hypothesis of finding no difference in the perspective of executives as to whether they intentionally held on to and maintained short-term liquid assets with their company in comparison to the choices of other executives.

However, we discovered significant differences in perception for other specific actions. The Federal Reserve's large scale-asset purchases during the first phase of quantitative easing pushed interest rates lower, especially for mortgagebased securities and Treasuries. Hassett (2014) posited that the reduction in interest rates could drive investors to substitute other assets for bonds, and that during the recovery phase of quantitative easing, rises in equity markets might suggest the Fed was inflating a stock-market bubble. In our survey, the relative perceptions of respondents showed a significant difference in the perception of the role companies played in contributing to an asset bubble. Respondents felt that others contributed to an asset bubble in the equity markets significantly more than they did individually, with approximately $31 \%$ of others contributing compared to their $13 \%$.

This holds true as well for the impact of the Fed's forward guidance policy on strategic planning. Specifically, the question asked participants to what degree "the Fed's forward guidance policy affected your strategic planning more than it had before the recession" and to what degree "the Fed's forward guidance policy affected strategic planning for 
business leaders more than it had before the recession."Whereas $51 \%$ of individuals agreed to forward guidance having at least somewhat of an impact, this compared to $77 \%$ that agreed it at least somewhat had an impact on overall business leaders. Similarly, we inquired whether perceptions about whether companies boosted dividends and share repurchases to bounce back from the recession.Only $13 \%$ of respondents admitted to personally making this decision. However, 54\% believed that this was a decision that business executives made in response to the recession. This strong and statistically significant difference offered evidence that respondents believed companies boosted dividends and share repurchases, but did not change their own decisions.

\section{Conclusion}

In reviewing the overall results from the survey of executives, there was consistent evidence that respondents believed that quantitative easing had a much stronger impact on other executives than for themselves personally. There could be many reasons behind these results. There wasconsensus that quantitative easing did lead to stabilization of financial markets and supported economic recovery. In reviewing the supplemental survey data, $80 \%$ of the executives surveyed at least somewhat agreed that "unconventional monetary policies were warranted to bring the U.S. economy out of the 2008 recession" and $71 \%$ at least somewhat agreed "quantitative easing was an appropriately aggressive policy under the circumstances in 2008." This is interesting because this shows how important executives thought quantitative easing was in the economic recovery. It would seem natural to think that it would be at the forefront of executivedecision-making.

We also looked for any significant differences due to the demographic characteristics of the respondents. However, there were no differences in our base conclusions based upon position, industry, or other demographic factors.

It is possible that individuals could not identify quantitative easing as the specific reason for their decisions. However, it is of considerable interest that respondents in this survey clearly believed that quantitative easing did affect the decisions of others significantly more than for them personally. We believe that the results suggest that it is valuable to explore further agent-based explorations of economic and financial crises and other situations.

\section{References}

Bernanke, B. \&Gertler, M. (1995). Inside the Black Box: The Credit Channel of Monetary Policy Transmission. Journal of Economic Perspectives. 9 (4), 27-48.

Bhattarai, S., Chatterjee, A. \&Park, W. Y. (2015). Effects of US Quantitative Easing on Emerging Market Economies. Globalization and Monetary Policy Institute Working Paper No. 255, Federal Reserve Bank of Dallas. November.

Blinder, A. S. (2010). Quantitative easing: Entrance and Exit Strategies.Federal Reserve Bank of St. Louis Review. November/December, 465-479.

Bookstaber, R. (2017). The End of Theory: Financial Crises, the Failure of Economics, and the Sweep of Human Interaction. Princeton: Princeton University Press.

Carlson, J. \&Wakefield, S. (2009). A Focus on Quantitative Easing.Economic Trends, Federal Reserve Bank of Cleveland. January,6-7.

Carlson, J. B., Haubrich, J. G., Cherny, K., \&Wakefield, S.(2009). Credit Easing: A Policy for a Time of Financial Crisis. Economic Trends, Federal Reserve Bank of Cleveland. February, 7-13.

Gertler, M. \&Gilchrist S. (2018). What Happened: Financial Factors in the Great Recession. Journal of Economic Perspectives. 32 (3), 3-30.

Hassett, K. A. (2014). A Fed-Blown Bubble?National Review. August, 25.

Madera, A. G. (2019). Ways of People's Estimating Uncertain Quantitative Factors for Decision-Making in Economy and Business. Journal of Business \& Economic Policy. 6 (1), 117-120.

Montgomery, H. (1983). Decision Rules and the Search for a Dominance Structure: Towards a Process Model of Decision Making.Advances in Psychology. 14, 343-369.

Putnam, B. H. (2013). Essential Concepts Necessary to Consider when Evaluating the Efficacy of Quantitative Easing.Review of Financial Economics.22(1), 1-7.

Reinhart, C. M. \&Rogoff, K. (2009). This Time is Different: Eight Centuries of Financial Folly. Princeton: Princeton University Press.

Revel, J. \&Light, J. (2008). Three great thinkers - John Steele Gordon, Jeremy Grantham, and Diane Swonk - on how bad things are (or aren't) and what might come next. CNNMoney.com. (October 10, 2008)

Williams, J. C. (2013). Will Unconventional Policy Be the New Normal?Economic Letter. Federal Reserve Bank of San Francisco October 7, 1-8. 


\section{APPENDIX A SURVEY INSTRUMENT}

Demographic information

Current position: CEO, CFO, COO, Other C-Level, Other Managerial, Non-Managerial

Industry: Energy, Construction, Manufacturing, Information Technology, Finance \& Insurance, Health Care, Other-For Profit, Other-Nonprofit

Years of experience in industry: 1-5, 6-10, 11-15, 15-20, 20+

Point of Survey: The purpose of this research project is to examine the degree to which quantitative easing has affected the decision making of business executives.

\section{Background}

In 2008, the U.S. economy spiraled into a recession due to the collapse of the housing market. This caused banks and investors to stop lending, the stock market to endure its worst fall since the Great Depression, and unemployment to soar. On December 16, 2008, The Federal Open Market Committee (FOMC) stepped in to establish a target for the federal funds rate at $0 \%$ to $0.25 \%$. Unconventional monetary policies were also introduced. This included large-scale asset repurchases, otherwise known as quantitative easing $(\mathrm{QE})$, and forward policy guidance, which is communicated likely future Fed policy actions. The monetary base jumped from $\$ 850$ billion in late August 2008 to almost $\$ 1.7$ trillion at the end of 2008 .

$\underline{\text { You }}$

Please answer these questions based on the decisions you personally made in reaction to QE as you understood it since 2008.

\begin{tabular}{|c|c|c|c|c|c|c|}
\hline $\begin{array}{l}\text { Strongly } \\
\text { Disagree }\end{array}$ & Disagree & $\begin{array}{l}\text { Somewhat } \\
\text { Disagree }\end{array}$ & $\begin{array}{l}\text { Neither } \\
\text { Agree nor } \\
\text { Disagree }\end{array}$ & $\begin{array}{c}\text { Somewhat } \\
\text { Agree }\end{array}$ & Agree & $\begin{array}{l}\text { Strongly } \\
\text { Agree }\end{array}$ \\
\hline
\end{tabular}

- You intentionally held on to and maintained short-term liquid assets within your company due to QE.

- You are concerned that decisions you made since the recession may have contributed to an asset bubble.

- QE impacted your short-term decisions as a business leader.

- QE impacted your long-term decisions as a business leader.

- The Fed's forward guidance policy affected your strategic planning more than it had before the recession.

- Your company boosted dividends and share repurchases to bounce back from the recession.

\section{Executives}

For this section please answer these questions as you believe business executives and leaders as a whole reacted to QE.

\begin{tabular}{|c|c|c|c|c|c|}
\hline $\begin{array}{l}\text { Strongly Disagree } \\
\text { Disagree }\end{array}$ & $\begin{array}{c}\text { Somewhat } \\
\text { Disagree }\end{array}$ & $\begin{array}{l}\text { Neither } \\
\text { Agree nor }\end{array}$ & $\begin{array}{c}\text { Somewhat } \\
\text { Agree }\end{array}$ & Agree & $\begin{array}{l}\text { Strongly } \\
\text { Agree }\end{array}$ \\
\hline
\end{tabular}

- Business executives intentionally held on to and maintained short-term liquid assets due to QE.

- Companies contributed to an asset bubble in the current equity market.

- Consumers contributed to an asset bubble in the current equity market.

- QE impacted business leaders' short-term decisions.

- QE impacted business leaders' long-term decisions.

- The Fed's forward guidance policy affected strategic planning for business leaders more than it had before the recession.

- Executives boosted dividends and share repurchases to bounce back from the recession.

- Improvements in consumer confidence were an important driver in the economic recovery over the past eight years. 
- Supply side factors played a bigger role than demand side factors in the economic recovery.

Please answer the following questions given the circumstances outlined in the background paragraph above.

\begin{tabular}{|c|c|c|c|c|c|c|}
\hline $\begin{array}{l}\text { Strongly } \\
\text { Disagree }\end{array}$ & Disagree & $\begin{array}{c}\text { Somewhat } \\
\text { Disagree } \\
\text { Disagr }\end{array}$ & $\begin{array}{l}\text { Neither } \\
\text { Agree nor }\end{array}$ & $\begin{array}{c}\text { Somewhat } \\
\text { Agree }\end{array}$ & Agree & $\begin{array}{l}\text { Strongly } \\
\text { Agree }\end{array}$ \\
\hline
\end{tabular}

- Unconventional monetary policies were warranted to bring the U.S. economy out of the 2008 recession.

- QE was an appropriately aggressive policy under the circumstances in 2008.

- The initial interest rate change positively impacted the borrowing habits of corporations.

- The rate of growth of the U.S. economy since 2008 would have been higher if a more conservative approach had been taken by the Federal Reserve.

- I have a positive outlook for the long-term effects of QE.

- Looking forward, I have confidence in the Federal Reserve's decisions. 